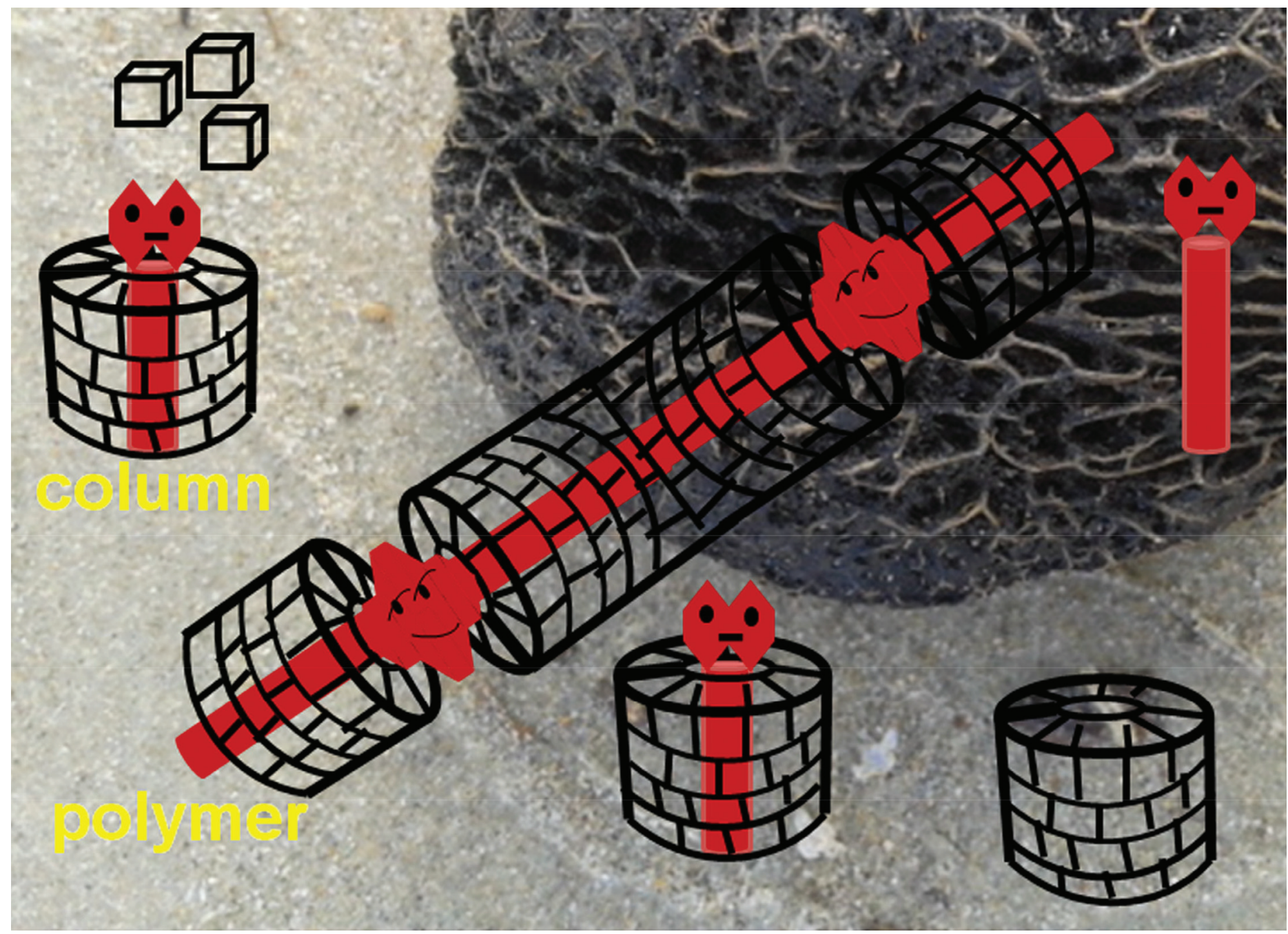

Showcasing research from the Debasish Haldar lab, Indian Institute of Science Education and Research Kolkata (see http://www.iiserkol.ac.in/people/faculty/dcs/deba_h76).

A self-assembled peptide mimetic of a tubular host and a supramolecular polymer

The tripeptide self-assembles in a helical manner to form a tubular host-like supramolecular nanotube with a hydrophobic core, which has been used to develop a supramolecular polymer.

\section{As featured in:}

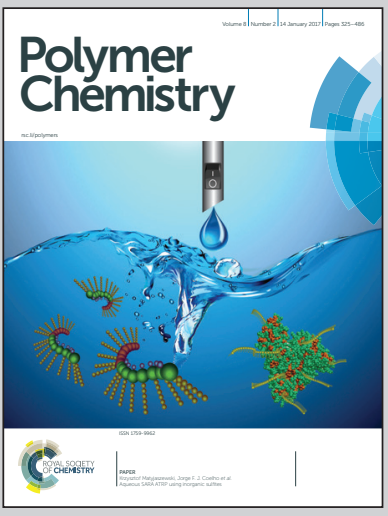

See Debasish Haldar et al., Polym. Chem., 2017, 8, 396.

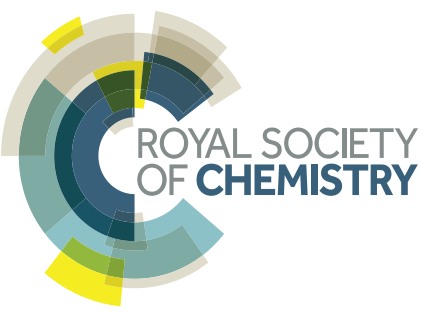




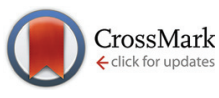

Cite this: Polym. Chem., 2017, 8, 396

\title{
A self-assembled peptide mimetic of a tubular host and a supramolecular polymer $\dagger$
}

\author{
Arpita Paikar, Apurba Pramanik, Tanmay Das and Debasish Haldar*
}

Simple and efficient strategies for the generation of a supramolecular nanotube by self-assembly of acyclic modular building blocks and guest encapsulation remain an essentially unmet challenge. A tripeptide containing leucine, Aib and serine forms a rigid type-III' $\beta$-turn structure stabilized by multiple intramolecular $\mathrm{N}-\mathrm{H} \cdots \mathrm{O}$ and $\mathrm{O}-\mathrm{H} \ldots \mathrm{O}$ hydrogen bonds. The modular building blocks self-assemble in a helical manner to develop a supramolecular nanotube. The formation of a self-assembled peptide mimetic of the nanotubular host has been proven with SEM, X-ray crystallography and other spectroscopic techniques. This supramolecular nanotube with a hydrophobic core has been used as the host for modular inclusion of designer hydrophobic guests to fabricate a supramolecular polymer. The interactions between the host and the guest were analyzed by using DLS and different spectroscopic techniques. The variable temperature NMR experiments show that with the increasing temperature the hydrophobic interactions between the host and the guest decrease, which indicates the sliding of the tubular host along the guest axle. Comparison of a coumarin based guest with a naphthalenediimide based guest shows that the latter have connected two tubular hosts and thus formed a supramolecular polymer. The formation of the supramolecular polymer has been proven with DLS, SEM and AFM and other spectroscopic techniques.

Received 8th November 2016 Accepted 20th November 2016 DOI: $10.1039 / c 6 p y 01955 b$ www.rsc.org/polymers actions. $^{3}$ These non-covalent interactions cover hydrogen bonding, $\pi$-stacking interactions, van der Waals interactions, ionic and polar interactions and hydrophobic collapse. ${ }^{3}$ A large number of supramolecular oligomers and polymers encapsulated by a tubular host have been reported. ${ }^{4,5}$ These host-guest complexes are important as supramolecular catalysts, ${ }^{6}$ enzymes, ${ }^{7}$ advance optical materials ${ }^{8}$ and find several applications. ${ }^{9}$ The tubular host may rotate around the guest or it may slide along the guest axle. The movement of the tubular host may be manipulated by the external stimuli. ${ }^{10}$ A large number of foldamers that form helices and tubular structures and recognise small guests such as ions and small molecules have been reported. ${ }^{11}$ But fabrication of a cylindrical host or tube by assembly of acyclic modular building blocks is relatively rare. $^{12}$

We are looking for a supramolecular assembly of peptides into hollow helices that can encapsulate various guests. ${ }^{13}$ For this we have synthesized many Xaa-Aib-Xaa tripeptides, most have a $\beta$-turn structure, and self-assemble to form a supramolecular helix, but none form nanotubes. Herein, we have synthesized a tripeptide containing L-Leu, $\alpha$-aminoisobutyric acid (Aib) and L-Ser with an assumption that the helicogenic $\mathrm{Aib}^{14}$ core leads to the hydrogen bonded folded structure and the L-Ser side chain may incorporate additional hydrogen bonding (Scheme 1). For the inclusion study guest molecules, the coumarin derivative 2 and naphthalene diimide 3 , with long 

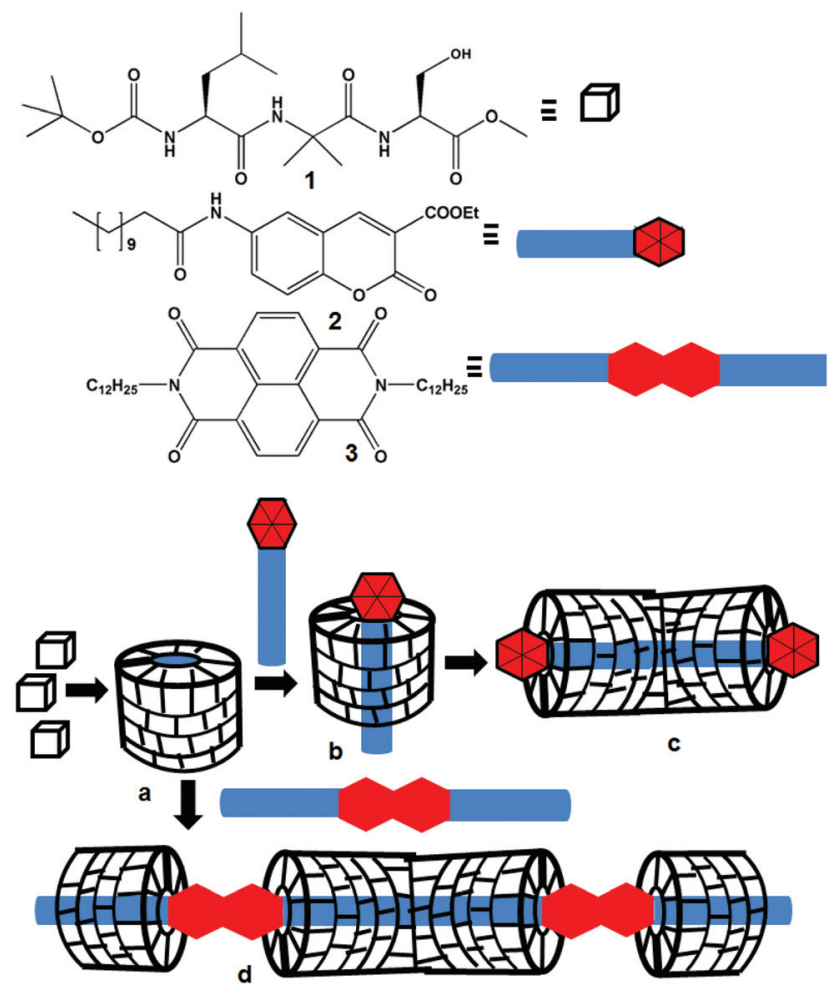

Scheme 1 Compounds 1, 2 and 3 and the schematic presentation of (a) the supramolecular helical nanotube from peptide building blocks; (b) inclusion of the hydrophobic compound in the capsid; (c) the supramolecular columnar structure; (d) the supramolecular inclusion polymer.

hydrophobic chains have been synthesized. The supramolecular assembly of peptides may provide hollow helices (Scheme 1a), which will behave like a modular host depending on the structure of the guest molecule. The host peptide has no chromophore. So, a chromophore containing guest will be helpful to study the interactions by various spectroscopic techniques. We incorporate coumarin and naphthaline diimide as the core units in the guest molecules. We propose that the coumarin derivative 2 having one hydrophobic tail will interact with the nanotube by incorporating its hydrophobic tail inside the nanotube (Scheme 1b) and finally develop a supramolecular rod-like structure (Scheme 1c). However, one naphthalene diimide 3 unit having two hydrophobic tails will connect two host nanotubes and thus develops a supramolecular polymer (Scheme 1d).

\section{Experimental}

\section{Materials}

All L-amino acids were purchased from Sigma chemicals. HOBt (1-hydroxybenzotriazole) and DCC (dicyclohexylcarbodiimide) were purchased from SRL.

\section{Peptide synthesis}

The peptides were synthesized by a conventional solutionphase method using a racemization free fragment conden- sation strategy. The Boc group was used for N-terminal protection and the C-terminus was protected as a methyl ester. Couplings were mediated by dicyclohexylcarbodiimide/ 1-hydroxybenzotriazole (DCC/HOBt). Methyl ester deprotection was performed via the saponification method. All the intermediates were characterized by $500 \mathrm{MHz}{ }^{1} \mathrm{H} \mathrm{NMR},{ }^{13} \mathrm{C} \mathrm{NMR}$ and mass spectrometry. Final compounds were fully characterized by $500 \mathrm{MHz}{ }^{1} \mathrm{H}$ NMR spectroscopy, ${ }^{13} \mathrm{C}$ NMR spectroscopy, mass spectrometry, and IR spectroscopy. Peptide 3 was characterized by X-ray crystallography. The products were purified by column chromatography using silica (100-200 mesh size) gel as the stationary phase and the $n$-hexane-ethyl acetate mixture as the eluent.

Boc-Leu(1)-OH. A solution of L-leucine $(2.62 \mathrm{~g}, 20 \mathrm{mmol})$ in a mixture of dioxane $(40 \mathrm{ml})$, water $(20 \mathrm{ml})$ and $1 \mathrm{M} \mathrm{NaOH}$ $(20 \mathrm{ml})$ was stirred and cooled in an ice-water bath. Di-tertbutyl pyrocarbonate $(4.8 \mathrm{~g}, 22 \mathrm{mmol})$ was added and stirring was continued at room temperature for $6 \mathrm{~h}$. Then the solution was concentrated in a vacuum to about $20-30 \mathrm{ml}$, cooled in an ice water bath, covered with a layer of ethyl acetate (about $50 \mathrm{ml}$ ) and acidified with a dilute solution of $\mathrm{KHSO}_{4}$ to $\mathrm{pH} 2-3$ (Congo red). The aqueous phase was extracted with ethyl acetate and this operation was done repeatedly. The ethyl acetate extracts were pooled, washed with water and dried over anhydrous $\mathrm{Na}_{2} \mathrm{SO}_{4}$ and evaporated under vacuum. The pure material was obtained as a waxy solid. Yield: $3.80 \mathrm{~g}$ (16.4 mmol, 82.0\%).

${ }^{1} \mathrm{H}$ NMR (500 MHz, DMSO- $d_{6}, \delta$ in ppm): $12.36[\mathrm{~b}, 1 \mathrm{H}$, $\mathrm{COOH}], 7.03-7.02[\mathrm{~d}, 1 \mathrm{H}, J=2 \mathrm{~Hz}, \operatorname{Leu}(1) \mathrm{NH}], 3.91-3.87$ $\left[\mathrm{m}, 1 \mathrm{H}, \operatorname{Leu}(\mathbf{1}) \mathrm{C}^{\alpha} \mathrm{H}\right], 1.63-1.60\left[\mathrm{~m}, 2 \mathrm{H}, \operatorname{Leu}(\mathbf{1}) \mathrm{C}^{\beta} \mathrm{H}\right], 1.51-1.47$ $\left[\mathrm{m}, 1 \mathrm{H}, \operatorname{Leu}(\mathbf{1}) \mathrm{C}^{\gamma} \mathrm{H}\right], 1.37[\mathrm{~s}, 9 \mathrm{H}$, Boc $], 0.87-0.83[\mathrm{~m}, 12 \mathrm{H}$, $\left.4 \mathrm{CH}_{3}\right] .{ }^{13} \mathrm{C}$ NMR $\left(125 \mathrm{MHz}, \mathrm{DMSO}-d_{6}, \delta\right.$ in ppm): 174.73, 155.64, 77.76, 66.41, 51.81, 28.24, 24.38, 22.29. FT-IR (KBr): 3462, 3355, 3311, 2983, 2968, 2934, 2877, 2525, 1727, 1699, 1675,1533 , 1456, 1419, 1385, 1368, 1296, 1197, 1172, 1087, 1048, $1018 \mathrm{~cm}^{-1}$.

Boc-Leu(1)-Aib(2)-OMe. $3.75 \mathrm{~g}$ (16.22 mmol) of Boc-Leu-OH was dissolved in $25 \mathrm{ml}$ dry DCM in an ice-water bath. H-AibOMe $4.915 \mathrm{~g}$ (32 mmol) was isolated from the corresponding methyl ester hydrochloride by neutralization, subsequent extraction with ethyl acetate and solvent evaporation. It was then added to the reaction mixture, followed immediately by $3.34 \mathrm{~g}$ (16.22 mmol) dicyclohexylcarbodiimide (DCC) and $2.48 \mathrm{~g}(16.22 \mathrm{mmol})$ of HOBt. The reaction mixture was allowed to reach room temperature and stirred for $48 \mathrm{~h}$. DCM was evaporated and the residue was dissolved in ethyl acetate $(60 \mathrm{ml})$ and dicyclohexylurea (DCU) was filtered off. The organic layer was washed with $2 \mathrm{M} \mathrm{HCl}(3 \times 50 \mathrm{~mL})$, brine $(2 \times$ $50 \mathrm{~mL}), 1 \mathrm{M}$ sodium bicarbonate $(3 \times 50 \mathrm{~mL})$ and brine $(2 \times$ $50 \mathrm{~mL}$ ) and dried over anhydrous $\mathrm{Na}_{2} \mathrm{SO}_{4}$, and evaporated in a vacuum to yield Boc-Leu-Aib-OMe as a white solid. The product was purified by silica gel (100-200 mesh) using $n$ hexane-ethyl acetate $(3: 1)$ as an eluent. Yield: $4.17 \mathrm{~g}$ (12.62 mmol, 77.8\%).

${ }^{1} \mathrm{H} \mathrm{NMR}\left(\mathrm{CDCl}_{3}, 500 \mathrm{MHz}, \delta\right.$ in $\left.\mathrm{ppm}\right): 6.60[\mathrm{~s}, 1 \mathrm{H}, \mathrm{Aib}(2)$ $\mathrm{NH}], 4.78[\mathrm{~b}, 1 \mathrm{H}, \operatorname{Leu}(\mathbf{1}) \mathrm{NH}], 3.98\left[\mathrm{~b}, 1 \mathrm{H}\right.$, Leu $\left.(\mathbf{1}) \mathrm{C}^{\alpha} \mathrm{H}\right], 3.66$ 
[s, 3H, OMe], 1.62-1.55 [m, 2H, Leu(1) $\left.\mathrm{C}^{\beta} \mathrm{H}\right], 1.46[\mathrm{~s}, 6 \mathrm{H}, \operatorname{Aib}(2)$ $\mathrm{C}^{\beta} \mathrm{H}$ ], 1.41 [s, 9H, Boc], 0.88-0.85 [m, 7H, Leu(1) $\left.\mathrm{C}^{\delta} \mathrm{H}+\mathrm{C}^{\gamma} \mathrm{H}\right]$. ${ }^{13} \mathrm{C} \mathrm{NMR}\left(\mathrm{CDCl}_{3}, 125 \mathrm{MHz}, \delta\right.$ in ppm): 174.74, 171.73, 155.83, 80.07 , 56.37, 56.37, 52.95, 52.53, 40.82, 28.26, 24.74, 24.70, 24.67, 22.86, 22.06. FT-IR (KBr): 3323, 3078, 2959, 2872, 1748, 1685, 1534, 1458, 1393, 1366, 1320, 1281, 1247, $1153 \mathrm{~cm}^{-1}$.

Boc-Leu(1)-Aib(2)-OH. To $4.13 \mathrm{~g}(12.5 \mathrm{mmol})$ of compound $3,25 \mathrm{ml} \mathrm{MeOH}$ and $15 \mathrm{ml}$ of $2 \mathrm{M} \mathrm{NaOH}$ were added and the progress of saponification was monitored by thin layer chromatography (TLC). The reaction mixture was stirred and after $10 \mathrm{~h}$, methanol was removed under vacuum, the residue was dissolved in $50 \mathrm{ml}$ of water, and washed with diethyl ether $(2 \times 50 \mathrm{~mL})$. Then the $\mathrm{pH}$ of the aqueous layer was adjusted to 2 using $1 \mathrm{M} \mathrm{HCl}$ and it was extracted with ethyl acetate $(3 \times 50 \mathrm{~mL})$. The extract was pooled, dried over anhydrous sodium sulfate, and evaporated under vacuum to obtained compound 6 as a white solid. Yield $3.43 \mathrm{~g}$ (10.85 mmol, 86.8\%).

${ }^{1} \mathrm{H}$ NMR (DMSO- $d_{6}, 500 \mathrm{MHz}, \delta$ in ppm): $12.20[\mathrm{~s}, 1 \mathrm{H}$, $\mathrm{COOH}], 7.92[\mathrm{~s}, 1 \mathrm{H}, \operatorname{Aib}(\mathbf{1}) \mathrm{NH}], 6.74-6.72[\mathrm{~d}, 1 \mathrm{H}, J=9 \mathrm{~Hz}$, Leu(1) NH], 3.98-3.34 [m, 1H, Leu(1) $\left.\mathrm{C}^{\alpha} \mathrm{H}\right], 1.63-1.56[\mathrm{dd}, 2 \mathrm{H}$, $\left.\operatorname{Leu}(1) \mathrm{C}^{\beta} \mathrm{H}\right], 1.37$ [s, 6H, $\left.\operatorname{Aib}(2) \mathrm{C}^{\beta} \mathrm{H}\right], 1.32[\mathrm{~s}, 9 \mathrm{H}, \operatorname{Boc}]$, 0.89-0.84 [m, 7H, Leu(1) $\left.\mathrm{C}^{\delta} \mathrm{H}+\mathrm{C}^{\gamma} \mathrm{H}\right] \cdot{ }^{13} \mathrm{C}$ NMR (DMSO- $d_{6}$, $125 \mathrm{MHz}, \delta$ in ppm): 175.43, 171.69, 155.16, 77.91, 54.72, $52.44,40.97,28.14,24.65,24.12,22.96,21.60$. FT-IR (KBr): 3308, 3067, 1665, 1528, 1376, 1284, $1171 \mathrm{~cm}^{-1}$.

Boc-Leu(1)-Aib(2)-Ser(3)-OMe. $3.4 \mathrm{~g}$ (10.774 mmol) Boc-LeuAib-OH was dissolved in $15 \mathrm{ml}$ dry DCM in an ice-water bath. $3.38 \mathrm{~g}$ (22 mmol) H-Ser-OMe was isolated from the corresponding methyl ester hydrochloride by neutralization, subsequently extracted with ethyl acetate and concentrated to $7 \mathrm{ml}$. Then it was added to the reaction mixture, followed immediately by $2.222 \mathrm{~g}(10.774 \mathrm{mmol})$ dicyclohexylcarbodiimide (DCC) and $1.649 \mathrm{~g}$ (10.774 mmol) HOBt. The reaction mixture was allowed to reach room temperature and stirred for $72 \mathrm{~h}$. The residue was taken into $30 \mathrm{~mL}$ ethyl acetate and dicyclohexylurea (DCU) was filtered off. The organic layer was washed with $2 \mathrm{M} \mathrm{HCl}(3 \times 50 \mathrm{~mL})$, brine $(2 \times 50 \mathrm{~mL})$, then $1 \mathrm{M}$ sodium bicarbonate $(3 \times 30 \mathrm{~mL})$ and brine $(2 \times 30 \mathrm{~mL})$ and dried over anhydrous sodium sulfate and evaporated under vacuum to yield tripeptide $\mathbf{1}$ as an off-white solid. Purification was done by using a silica gel column (100-200 mesh) and ethyl acetate and hexane (1:4) as an eluent. Yield: $4.06 \mathrm{~g}$ (8.5 mmol, 78.89\%).

${ }^{1} \mathrm{H} \mathrm{NMR} \mathrm{(} \mathrm{CDCl}_{3}, 500 \mathrm{MHz}, \delta$ in ppm): $7.0615[\mathrm{~b}, 1 \mathrm{H}, \operatorname{Ser}(3)$ $\mathrm{NH}], 6.7218$ [s, 1H, Aib(2) NH], 5.0348-5.0176 [d, 1H, Boc NH, $J=8.6 \mathrm{~Hz}], 4.5825-4.5634[\mathrm{t}, 1 \mathrm{H} \operatorname{Ser}(3) \mathrm{OH}], 4.0463-4.0196$ $\left[\mathrm{d}, 1 \mathrm{H}, \mathrm{C}^{\alpha} \mathrm{H} \operatorname{Leu}(\mathbf{1}), J=13.35 \mathrm{~Hz}\right], 3.9757-3.9222\left[\mathrm{~m}, 2 \mathrm{H}, \mathrm{C}^{\beta} \mathrm{H}\right.$ $\operatorname{Ser}(3)$ ], 3.8726-3.8344 [dd, $1 \mathrm{H}, \mathrm{C}^{\alpha} \mathrm{H}$ of $\left.\operatorname{Ser}(3)\right], 3.7524[\mathrm{~s}, 3 \mathrm{H}$, OMe], 1.6932-1.5711 [m, 2H, $\mathrm{C}^{\beta} \mathrm{H}$ Leu(1)], 1.5329-1.5119 [d, 6H, $2 \times$ Me of Aib, $J=10.5 \mathrm{~Hz}$ ], 1.4375 [s, 9H, Boc], 0.9490-0.9089 [m, 7H, Leu(1) $\left.\mathrm{C}^{\delta} \mathrm{H}+\mathrm{C}^{\gamma} \mathrm{H}\right] \cdot{ }^{13} \mathrm{C}$ NMR $\left(\mathrm{CDCl}_{3}\right.$, $125 \mathrm{MHz}, \delta$ in ppm): 174.0582, 173.5599, 171.4655, 156.8697, 81.4060, 62.6647, 57.6815, 57.7098, 53.0232, 40.6373, 28.8292, 26.8865, 25.3048, 24.7776, 23.4777, 22.4016. FT-IR (KBr): 3303, 2948, 1745, 1654, 1541, 1276, 1178, $1049 \mathrm{~cm}^{-1}$. Mass spectra: $m / z$ 440.2803, $[\mathrm{M}+\mathrm{Na}]^{+} ; M_{\text {calcd }}$ 417.25.
Synthesis of coumarin. $2 \mathrm{~mL}(18.6 \mathrm{mmol})$ of salicylaldehyde, $2.8 \mathrm{~mL}$ of diethyl malonate and $200 \mu \mathrm{L}$ of piperidine were taken in a $50 \mathrm{~mL}$ round bottom flask and refluxed at $80^{\circ} \mathrm{C}$ for $10 \mathrm{~h}$ with continuous stirring. The reaction mixture was cooled to room temperature and washed with water. Ethyl acetate was added and shaken vigorously. The ethyl acetate layer was collected and dried over anhydrous $\mathrm{Na}_{2} \mathrm{SO}_{4}$. The product coumarin ester was purified by column chromatography using silica gel (60-120 mesh) as a stationary stage and ethyl acetate and hexane $(1: 1)$ as an eluent. Yield: $2.80 \mathrm{~g}$ (12.83 mmol, $68.97 \%)$.

${ }^{1} \mathrm{H}$ NMR (400 MHz, $\mathrm{CDCl}_{3}, \delta$ in ppm): 8.52 (s, $1 \mathrm{H}$ lactone ring proton); $7.62(\mathrm{~m}, 2 \mathrm{H}$, phenyl ring protons); $7.36(\mathrm{~m}, 2 \mathrm{H}$, phenyl ring protons); $4.42\left(\mathrm{~m}, 2 \mathrm{H}, \mathrm{CH}_{2}\right) ; 1.42\left(\mathrm{t}, 3 \mathrm{H}, \mathrm{CH}_{3}\right)$; ${ }^{13} \mathrm{C}$ NMR $\left(100 \mathrm{MHz}, \mathrm{CDCl}_{3}\right): \delta 162.99,156.67,155.08,148.55$, 134.28, 129.44, 124.78, 118.24, 117.80, 116.72, 61.92, 14.17.

Synthesis of 6-nitro coumarin. $2.78 \mathrm{~g}(12.75 \mathrm{mmol})$ of coumarin ester was dissolved in $6.37 \mathrm{~mL}$ of conc. $\mathrm{H}_{2} \mathrm{SO}_{4}$ and stirred at $0{ }^{\circ} \mathrm{C}$ for $15 \mathrm{~min}$. Then the mixture of $2.95 \mathrm{~mL}$ (55.46 mmol) nitric acid and $2.44 \mathrm{~mL}(58.65 \mathrm{mmol})$ of $\mathrm{H}_{2} \mathrm{SO}_{4}$ was added dropwise and stirred for $1 \mathrm{~h}$. The temperature was maintained within the range $0-5{ }^{\circ} \mathrm{C}$. Then the reaction mixture was poured into ice-water and filtered. The residue was washed with fresh water repetitively and dried. The product nitro coumarin ester was purified by column chromatography using a silica gel column (100-200 mesh) and ethyl acetate: hexane $(2: 1)$ as an eluent. Yield: $2.5 \mathrm{~g}(9.5 \mathrm{mmol}$, $74.5 \%)$.

${ }^{1} \mathrm{H}$ NMR (400 MHz, $\mathrm{CDCl}_{3}, \delta$ in ppm): 8.58 (s, $1 \mathrm{H}$ phenyl ring proton); $7.56(\mathrm{~s}, 1 \mathrm{H}$, lactone ring protons); 8.50-8.47 (d, $1 \mathrm{H}, J=12.4$, phenyl ring protons); 7.51-7.49 (d, $1 \mathrm{H}, J=8.8$, phenyl ring protons); $4.46\left(\mathrm{~m}, 2 \mathrm{H}, \mathrm{CH}_{2}\right) ; 1.43\left(\mathrm{t}, 3 \mathrm{H}, \mathrm{CH}_{3}\right)$; ${ }^{13} \mathrm{C}$ NMR $\left(100 \mathrm{MHz}, \mathrm{CDCl}_{3}\right): \delta$ 162.01, 158.29, 154.93, 146.88, 144.19, 128.56, 125.18, 120.52, 118.05, 62.51, 14.14 .

Synthesis of 6-amino coumarin. $2.4 \mathrm{~g}(9.12 \mathrm{mmol})$ of nitro coumarin ester was dissolved in $30 \mathrm{~mL}$ ethanol and $4.11 \mathrm{~g}$ (18.24 $\mathrm{mmol}$ ) of stannous chloride (dehydrate) was added and refluxed for $2 \mathrm{~h}$ with continuous stirring. The reaction mixture was cooled to room temperature and the product amino coumarin ester was purified by column chromatography using a silica gel column (100-200 mesh) and ethyl acetate : hexane $(4: 1)$ as an eluent.

Yield: $1.25 \mathrm{~g}$ (5.36 mmol, 58.77\%).

${ }^{1} \mathrm{H}$ NMR (400 MHz, DMSO-D $6, \delta$ in ppm): 8.55 (s, $1 \mathrm{H}$ lactone ring proton); 7.16-7.14 (d, $1 \mathrm{H}, J=9.2$, phenyl ring proton); 6.98-6.96 (d, $1 \mathrm{H}, J=9.8$, phenyl ring proton); 6.88 (s, $1 \mathrm{H}$, phenyl ring proton); $5.27\left(\mathrm{~s}, 2 \mathrm{H}, \mathrm{NH}_{2}\right) ; 4.29(\mathrm{~m}, 2 \mathrm{H}$, $\left.\mathrm{CH}_{2}\right) ; 1.31\left(\mathrm{t}, 3 \mathrm{H}, \mathrm{CH}_{3}\right) ;{ }^{13} \mathrm{C} \mathrm{NMR}\left(100 \mathrm{MHz}, \mathrm{DMSO}-\mathrm{D}_{6}\right)$ : $\delta 163.03,156.51,148.62,146.23,145.93,121.52,118.11$, 117.45, 116.51, 110.97, 61.09, 14.07 .

Coumarin derivative (2). $1.2 \mathrm{~g}(5.14 \mathrm{mmol})$ of amino coumarin ester was dissolved in $20 \mathrm{~mL}$ dry THF. $1.12 \mathrm{~g}$ (5.14 mmol) of $\mathrm{CH}_{3}\left(\mathrm{CH}_{2}\right)_{10} \mathrm{COCl}$ prepared from the corresponding lauric acid was added followed by addition of $714 \mu \mathrm{L}$ (5.14 mmol) $\mathrm{Et}_{3} \mathrm{~N}$ and stirred for $48 \mathrm{~h}$ at room temperature. THF was evaporated under vacuum, and the residue was 
dissolved in ethyl acetate and washed with $2 \mathrm{M} \mathrm{HCl}$ $(3 \times 50 \mathrm{~mL})$, brine $(2 \times 50 \mathrm{~mL}), 1 \mathrm{M}$ sodium carbonate $(3 \times 50 \mathrm{~mL})$ and brine $(2 \times 50 \mathrm{~mL})$ and dried over anhydrous sodium sulphate. The product coumarin 2 was purified by using a silica gel column (60-120 mesh size) and ethyl acetate and hexane $1: 2$ as an eluent. Yield: $1.462 \mathrm{~g}(3.52 \mathrm{mmol}$, $68.4 \%)$.

${ }^{1} \mathrm{H}$ NMR (400 MHz, $\mathrm{CDCl}_{3}, \delta$ in ppm): 8.44 (s, $1 \mathrm{H}$ lactone ring proton); 8.11-8.10 (d, $1 \mathrm{H}, J=4.2$, phenyl ring proton); 7.47-7.46 (d, $1 \mathrm{H}, J=2.4$, phenyl ring proton); 7.26 (s, $1 \mathrm{H}$, phenyl ring proton); 7.23 (t, 1H, NH); $4.37\left(\mathrm{~m}, 2 \mathrm{H}, \mathrm{CH}_{2}\right) ; 2.37\left(\mathrm{~m}, 2 \mathrm{H}, \mathrm{CH}_{2}\right)$; $1.69\left(\mathrm{~m}, 2 \mathrm{H}, \mathrm{CH}_{2}\right) ; 1.38\left(\mathrm{~m}, 3 \mathrm{H}, \mathrm{CH}_{3}\right) ; 1.25(\mathrm{~m}, 16 \mathrm{H}) ; 0.84(\mathrm{t}, 3 \mathrm{H}$, $\left.\mathrm{CH}_{3}\right) .{ }^{13} \mathrm{C} \mathrm{NMR}\left(100 \mathrm{MHz}, \mathrm{CDCl}_{3}\right): \delta 172.82,162.79,157.47$, $151.90,148.44,135.05,125.84,119.46,118.47,117.98,117.10$, $62.00,37.66,31.88,29.58,29.44,29.30,29.23,25.48,22.66$, 14.19, 14.08. ESI Mass $m / z 416.1(\mathrm{M}+\mathrm{H})^{+} M_{\text {cal }} 415.52$.

Synthesis of naphthalene diimide 3 . The compound has been synthesized following the standard diimide synthesis protocol as reported by P. Jana, S. K. Maity, S. Bera, P. K. Ghorai, D. Haldar, CrystEngComm, 2013, 15, 2512-2518.

${ }^{1} \mathrm{H}$ NMR $\left(\mathrm{CDCl}_{3}, 500 \mathrm{MHz}, \delta\right.$ in $\left.\mathrm{ppm}\right): 8.7536[\mathrm{~s}, 4 \mathrm{H}$, aromatic ring protons], 4.2040-4.1732 [t, 4H, $\mathrm{C}^{\alpha} \mathrm{H}$ of the Dodec chain], 1.7682-1.7077 [m, $4 \mathrm{H}, \mathrm{C}^{\beta} \mathrm{H}$ of the Dodec chain], 1.4405-1.3951 [m, $4 \mathrm{H}, \mathrm{CH}_{2}$ of the Dodec chain], 1.3718-1.3435 $\left[\mathrm{m}, 4 \mathrm{H}, \mathrm{CH}_{2}\right.$ of the Dodec chain], $1.2496\left[\mathrm{~s}, 32 \mathrm{H}, \mathrm{CH}_{2}\right.$ of the Dodec chain], 0.8866-0.8582 [t, 6H, $2 \times \mathrm{Me}$. ${ }^{13} \mathrm{C} \mathrm{NMR}\left(\mathrm{CDCl}_{3}\right.$, $125 \mathrm{MHz}, \delta$ in ppm): 173.447, 131.5220, 127.2686, 41.6015, 32.5026, 30.2206, 30.1773, 30.1123, 29.9245, 28.6824, 27.6787, 23.2664, 14.6947. ESI Mass $m / z 603.804[\mathrm{M}+\mathrm{H}]^{+} M_{\text {cal }} 602.41$.

\section{NMR experiments}

All NMR studies were carried out on Bruker AVANCE $500 \mathrm{MHz}$ and Jeol $400 \mathrm{MHz}$ spectrometers at $278 \mathrm{~K}$. Compound concentrations were in the range $1-10 \mathrm{mM}$ in $\mathrm{CDCl}_{3}$ and DMSO- $d_{6}$.

\section{FT-IR spectroscopy}

All reported solution FT-IR spectra were obtained with a Perkin Elmer Spectrum RX1 spectrophotometer.

\section{UV-Vis spectroscopy}

UV-Vis absorption spectra were recorded on a UV-Vis spectrophotometer (Hitachi).

\section{Fluorescence spectroscopy}

All the fluorescence spectra were recorded in DCM on a fluorescence spectrometer (HORIBA JOBIN YVON).

\section{Mass spectra}

Mass spectra were recorded on a Q-Tof Micro YA263 high resolution (Waters Corporation) mass spectrometer by positive-mode electrospray ionization.

\section{Dynamic light scattering}

The particle sizes were determined by using a DLS instrument (model ZETASIZER nano series nano zs) with the corresponding compound solution in DCM at different concentrations.

\section{Field emission scanning electron microscopy}

Morphologies of all the reported compounds were investigated using field emission-scanning electron microscopy (FE-SEM). A small amount of solution of the corresponding compound was placed on a clean silicon wafer and then dried by slow evaporation. The material was then allowed to dry under vacuum at $30{ }^{\circ} \mathrm{C}$ for two days. The materials were gold-coated, and the micrographs were obtained using FE-SEM apparatus (Jeol Scanning Microscope-JSM-6700F).

\section{Atomic force microscopy}

The morphology of the reported compound was investigated by atomic force microscopy (AFM). A drop of the sample solution in DCM was placed on a clean microscope cover glass and then dried by slow evaporation. The material was then allowed to dry under vacuum at $30{ }^{\circ} \mathrm{C}$ for two days. Images were obtained with an NTMDT instrument, model no. AP-0100 in semi-contact mode.

\section{Single crystal X-ray diffraction}

Crystallographic data of peptide 1: $\mathrm{C}_{19} \mathrm{H}_{35} \mathrm{~N}_{3} \mathrm{O}_{7}, M_{\mathrm{w}}=417.50$, hexagonal, space group $P 65, a=19.7793(8), b=19.7793(8), c=$ 11.2095(7) А, $V=3797.8(4) \AA 33, Z=6, \mathrm{dm}=1.095 \mathrm{Mg} \mathrm{m}^{-3}, T=$ $100 \mathrm{~K}, R_{1} 0.0591$ and $\mathrm{w} R_{2} 0.1625$ for 4990 data with $I>2 \sigma(I)$. Intensity data were collected with $\mathrm{MoK} \alpha$ radiation using a Bruker APEX-2 CCD diffractometer. Data were processed using the Bruker SAINT package and the structure solution and refinement procedures were performed using SHELX9718 and deposited at CCDC with reference 1434362.

\section{Results and discussion}

\section{Peptide structure analysis}

Target compounds were synthesized by conventional solution phase methods, and purified and characterized by ${ }^{1} \mathrm{H}-\mathrm{NMR}$, ${ }^{13} \mathrm{C}-\mathrm{NMR}$, FT-IR and mass spectrometry (MS) analysis. X-ray diffraction sheds some light on the structure and self-assembly of tripeptide $\mathbf{1}$ at the atomic level. Colorless crystals of tripeptide $\mathbf{1}$ were suitable for X-ray crystallography and obtained from dichloromethane solution by slow evaporation. Tripeptide 1 crystallizes with one molecule in the asymmetric unit. The solid state structure (Fig. 1a) of tripeptide 1 shows that the peptide backbone adopts a type III' $\beta$-turn like conformation. ${ }^{13}$ There is a ten member intramolecular $\mathrm{N}-\mathrm{H} \cdots \mathrm{O}$ hydrogen bond between Boc $\mathrm{C}=\mathrm{O}$ and Ser $\mathrm{NH}$. Another ten member intramolecular $\mathrm{O}-\mathrm{H} \cdots \mathrm{O}$ hydrogen bond exists between Leu $\mathrm{C}=\mathrm{O}$ and Ser side chain $\mathrm{OH}$. These intramolecular hydrogen bonds made the $\beta$-turn building block very rigid. The existence of this rigid $\beta$-turn like conformation of tripeptide 1 in the solution state was also confirmed by circular dichroism (CD) spectroscopy (Fig. S1 in the ESI $\dagger$ ). The torsion angles around the central Aib residue appear to play a 

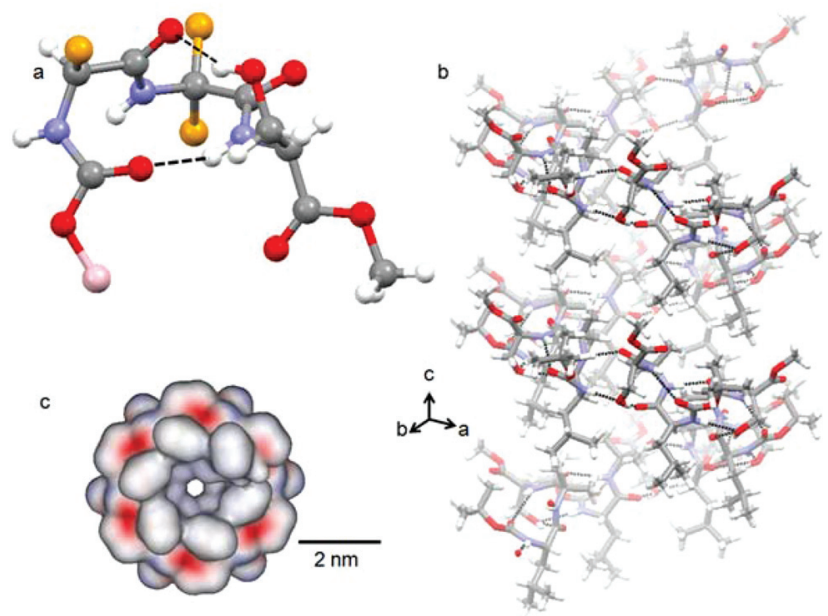

Fig. 1 (a) The solid state structure of peptide 1. Intramolecular hydrogen bonds are shown as black dotted lines. Leu and Aib side chains here appear as orange spheres and the $t$-butyl group as a pink sphere. (b) Side view of the intermolecular hydrogen bonded supramolecular helical column of tripeptide 1. Intermolecular hydrogen bonds are shown as black dotted lines. (c) Top view surface diagram of the supramolecular helical column of tripeptide 1 showing a hydrophobic inner core of the tube. The red colour indicates negative charge, blue positive charge and grey uncharged areas.

crucial role in dictating the overall structural features of tripeptide 1 (Table 1 in the ESI†).

The crystal structure further reveals that the individual tripeptide 1 subunits are stacked by intermolecular H-bonding interaction between neighboring molecules and generate a supramolecular helical column like structure (Fig. 1b) about the crystallographic $c$ direction. ${ }^{13}$ There are two intermolecular $\mathrm{N}-\mathrm{H} \cdots . \mathrm{O}$ hydrogen bonds between $\mathrm{Aib} \mathrm{C}=\mathrm{O}$ and Aib $\mathrm{NH}$ and Leu $\mathrm{NH}$ and Ser side chain $\mathrm{OH}$. The hydrogen bonding parameters of peptide 1 are listed (Table 2 in the ESI $\dagger$ ). The tripeptide 1 helix looks like a nanotube from a top view (Fig. 1c). The diameter of the tube is about $6 \AA$ and there is no restriction on the length. The surface diagrams (Fig. 1c) show that the inner core as well as the outside of the tube is hydrophobic in nature.

\section{DLS study of the inclusion complex}

We have intended to use the nanotubes for guest inclusion. The guest molecules 2 and $\mathbf{3}$ were designed with an assumption that the hydrophobic tail of the guests will be fitted inside the hydrophobic core of the nanotubes. The assembly behaviour of tripeptide $\mathbf{1}$ and guests was studied by dynamic light scattering (DLS). From the DLS study, the mixture of peptide 1 and coumarin derivative 2 forms bigger particles $(251 \mathrm{~nm})$ than the pure compounds $(60 \mathrm{~nm})$ (Fig. 2). However, the peptide 1 and naphthalene diimide 3 mixture forms the biggest particles (1130 $\mathrm{nm}$ ) as expected (Fig. 2).

\section{Spectroscopic studies of the inclusion complex}

The typical UV-Vis titration experiments of the coumarin derivative 2 in dichloromethane $\left(1.065 \times 10^{-5} \mathrm{M}\right)$ with tri-

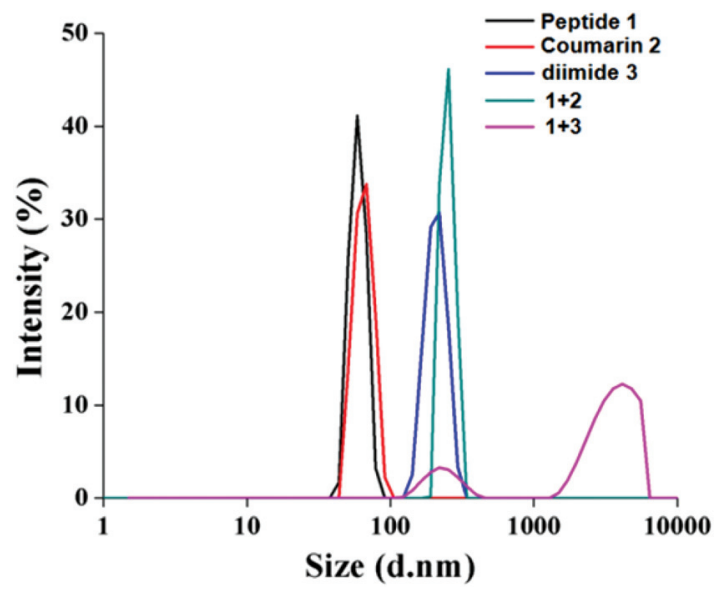

Fig. 2 DLS study of tripeptide $1\left(1.865 \times 10^{-5} \mathrm{M}\right)$, coumarin derivative $2\left(1.1990 \times 10^{-5} \mathrm{M}\right)$, naphthalene diimide $3\left(0.9732 \times 10^{-5} \mathrm{M}\right)$ and their mixtures in dichloromethane at room temperature.

peptide 1 show a gradual decrease of absorption bands at 250 , 294 and $365 \mathrm{~nm}$ responsible for $\pi$ to $\pi^{*}$ transition (Fig. S2 in the ESI $\dagger$ ). The UV-Vis titration experiments of naphthalene diimide 3 in dichloromethane $\left(2.41 \times 10^{-5} \mathrm{M}\right)$ with tripeptide 1 show similar results. With addition of tripeptide 1 , the intensity of the peaks at 240,356 and $386 \mathrm{~nm}$ responsible for $\pi$ to $\pi^{*}$ transition decreases (Fig. S3 in the ESI $\dagger$ ). The typical emission band of the coumarin derivative 2 in DCM solution at $460 \mathrm{~nm}$ also decreases with the addition of tripeptide 1 (Fig. S4 in the ESI $\uparrow$ ). From the emission spectra, the intensity of the peak at $401 \mathrm{~nm}$ for naphthalene diimide 3 also decreases with the addition of tripeptide 1 (Fig. S5 in the ESI $\dagger$ ). The results suggest the strong interactions between the tripeptide 1 and the coumarin derivative 2 or naphthalene diimide 3 . We have calculated the binding constant $\left(0.1473 \times 10^{4} \mathrm{M}^{-1}\right)$ of the peptide nanotube 1 and the coumarin derivative 2 using the Bensi-Hildebrand equation (Fig. S2b in the ESI $\dagger$ ). The binding constant for the peptide nanotube $\mathbf{1}$ and naphthalene diimide 3 is $0.1512 \times 10^{4} \mathrm{M}^{-1}$ (Fig. S3b in the ESI $\dagger$ ). Solution FT-IR spectroscopy is an excellent method to investigate the selfassembly propensity of tripeptide 1 and the coumarin derivative 2. The FT-IR region $3500-3200 \mathrm{~cm}^{-1}$ is important for the $\mathrm{N}-\mathrm{H}$ and $\mathrm{O}-\mathrm{H}$ stretching and $3000-2800 \mathrm{~cm}^{-1}$ for the $\mathrm{C}-\mathrm{H}$ stretching; however the range $1800-1500 \mathrm{~cm}^{-1}$ is assigned to the stretching band of amide I and the bending peak of amide II and ester groups. The FT-IR spectra of tripeptide 1 in DCM (Fig. 3a(i)) exhibits the $\mathrm{C}-\mathrm{H}$ stretching frequency at $2926 \mathrm{~cm}^{-1} \cdot 16$ The coumarin derivative 2 in DCM exhibits peaks at 2888 and $2815 \mathrm{~cm}^{-1}$ corresponding to the $\mathrm{C}-\mathrm{H}$ stretching frequency (Fig. 3a(ii)) which shifted to $2902 \mathrm{~cm}^{-1}$ on mixing with peptide 1 in DCM (Fig. 3a(iii)). This indicates the hydrophobic interactions between the tripeptide $\mathbf{1}$ and guest 2 .

In order to understand whether the amide and hydroxyl groups of peptide $\mathbf{1}$ are intramolecularly or intermolecularly hydrogen bonded, ${ }^{1} \mathrm{H}$ NMR solvent titration experiments have been performed. Generally, addition of small amounts of 

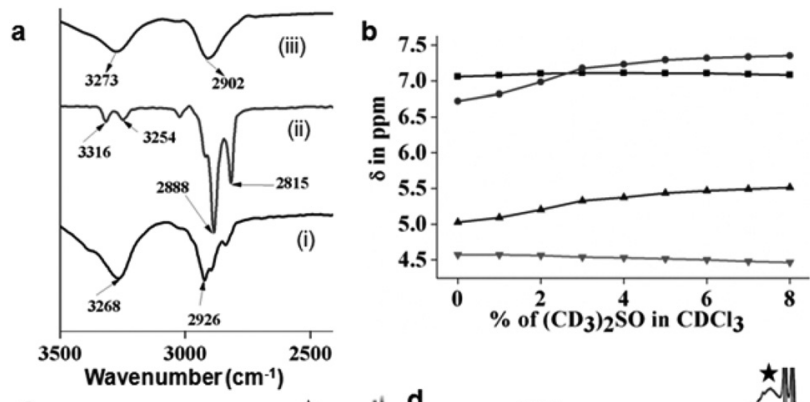

c
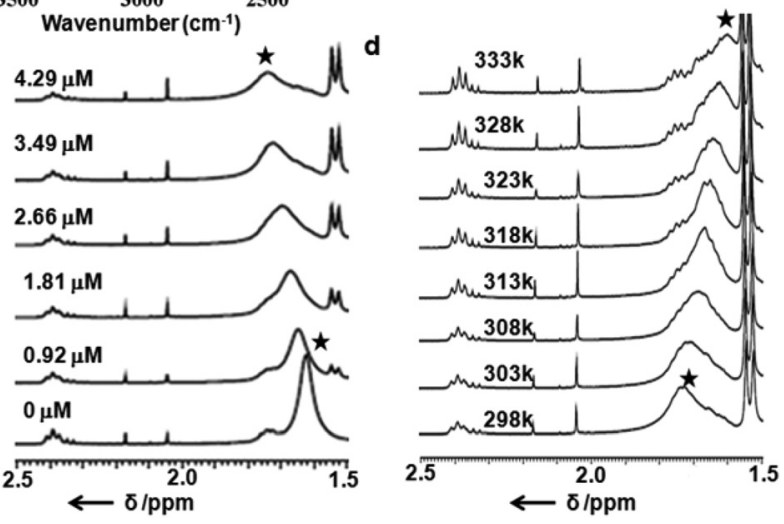

Fig. 3 (a) The solution FT-IR spectra of (i) peptide 1, (ii) coumarin derivative 2 and (iii) tripeptide 1 and coumarin derivative 2 mixture in DCM. (b) Plot of solvent dependence of the chemical shift of peptides 1 $(\boldsymbol{\nabla})$ Ser $\mathrm{OH},(\boldsymbol{\Delta})$ Leu $\mathrm{NH},(\boldsymbol{\bullet})$ Aib NH and (⿴) Ser NH at varying concentrations of $\left(\mathrm{CD}_{3}\right)_{2} \mathrm{SO}$ in $\mathrm{CDCl}_{3}$ solutions. (c) Part of ${ }^{1} \mathrm{H}$ NMR spectra of the coumarin derivative 2 with the increasing amount of peptide 1 in $\mathrm{CDCl}_{3}$. (d) Part of the variable temperature ${ }^{1} \mathrm{H}$ NMR spectra of the coumarin derivative 2 and peptide $1(4.29 \mu \mathrm{M})$ in $\mathrm{CDCl}_{3}$. ( $\star$ ) indicates hydrocarbon protons of the coumarin derivative 2 .

$\left(\mathrm{CD}_{3}\right)_{2} \mathrm{SO}$ in $\mathrm{CDCl}_{3}$ brings about monotonic downfield shifts of the exposed $\mathrm{NH}$ groups in peptides, leaving solvent-shielded $\mathrm{NH}$ groups largely unaffected. ${ }^{17}$ Fig. $3 \mathrm{~b}$ shows that Leu(1) and $\operatorname{Aib}(2)$ NHs are solvent exposed, as it is evident from their significant chemical shift ( $\Delta \delta 0.48$ and 0.63$)$, upon the addition of $\left(\mathrm{CD}_{3}\right)_{2} \mathrm{SO}$ to $\mathrm{CDCl}_{3}$ solutions. However, $\mathrm{Ser}(3) \mathrm{NH}$ and $\mathrm{OH}$ exhibit minimum chemical shifts $(\Delta \delta 0.02$ and 0.11$)$ even at higher percentages of $\left(\mathrm{CD}_{3}\right)_{2} \mathrm{SO}$. Table 3 in the ESI $\uparrow$ illustrates the chemical shift values of all NHs of peptide 1 . This demonstrates that peptide $\mathbf{1}$ has an intramolecular hydrogen bonded conformation in solution like that in the solid state. ${ }^{15}$ The typical NMR titration experiments of the coumarin derivative 2 in $\mathrm{CDCl}_{3}\left(1.1359 \times 10^{-4} \mathrm{M}\right)$ with tripeptide 1 show the gradual down field shift and broadening of hydrocarbon protons from 1.62 to $1.76 \mathrm{ppm}$ (Fig. 3c). This is due to the unique interaction between the tripeptide $\mathbf{1}$ and the coumarin derivative 2 . Other non-tubular peptides including a Met analogue do not affect the spectra in a similar manner (Fig. S6-S8 in the ESI†). Further we have studied the variable temperature NMR experiments of peptides 1 and the coumarin derivative 2 in $\mathrm{CDCl}_{3}$. Fig. $3 \mathrm{~d}$ shows the part of variable temperature ${ }^{1} \mathrm{H}$ NMR spectra of peptides 1 and the coumarin derivative 2 in $\mathrm{CDCl}_{3}$. Upon heating (from $25{ }^{\circ} \mathrm{C}$ to $60{ }^{\circ} \mathrm{C}$ ) the hydrocarbon protons at $1.76 \mathrm{ppm}$ shifted to an up-field direction (Fig. 3d). With the increasing temperature the interaction between the tripeptide 1 and the coumarin derivative 2 decreases. Ser(3) NH and $\mathrm{OH}$ of peptide 1 show no chemical shift with the increasing temperature, suggesting no change in intramolecular hydrogen bonding. However, Leu(1) and Aib(2) NHs exhibit very little chemical shift ( $\Delta \delta 0.05$ and 0.08$)$ even at higher temperatures. The supramolecular tube from tripeptide 1 encapsulates rod-like hydrophobic guests 2 .

\section{Morphological study}

The freshly prepared solution of peptide $\mathbf{1}$ in DCM $\left(0.5 \mathrm{mg} \mathrm{mL} \mathrm{m}^{-1}\right.$ ) was drop-cast on a silicon wafer and dried under vacuum at $30^{\circ} \mathrm{C}$ for two days. The FE-SEM micrographs show unbranched tube like aggregates with $100 \mathrm{~nm}$ average diameter and several micrometers in length (Fig. 4a). The coumarin derivative 2 from DCM solution exhibits a twisted fiber like morphology. The twisted fibers have a diameter of about $70 \mathrm{~nm}$ and are several micrometers in length (Fig. 4b). To examine the difference in the morphology after mixing peptide 1 and the coumarin derivative 2, FE-SEM was performed. The peptide 1 and coumarin derivative 2 mixture exhibits an unbranched polydisperse rod like morphology (Fig. 4c). The rods are hexagonal (Fig. 4c inset) in shape and rigid in nature. The average diameter of the rods is $c a .100 \mathrm{~nm}$ and length ca. $500 \mathrm{~nm}$ which may be obtained by interaction between coumarin molecules and the tubes. The existence of both

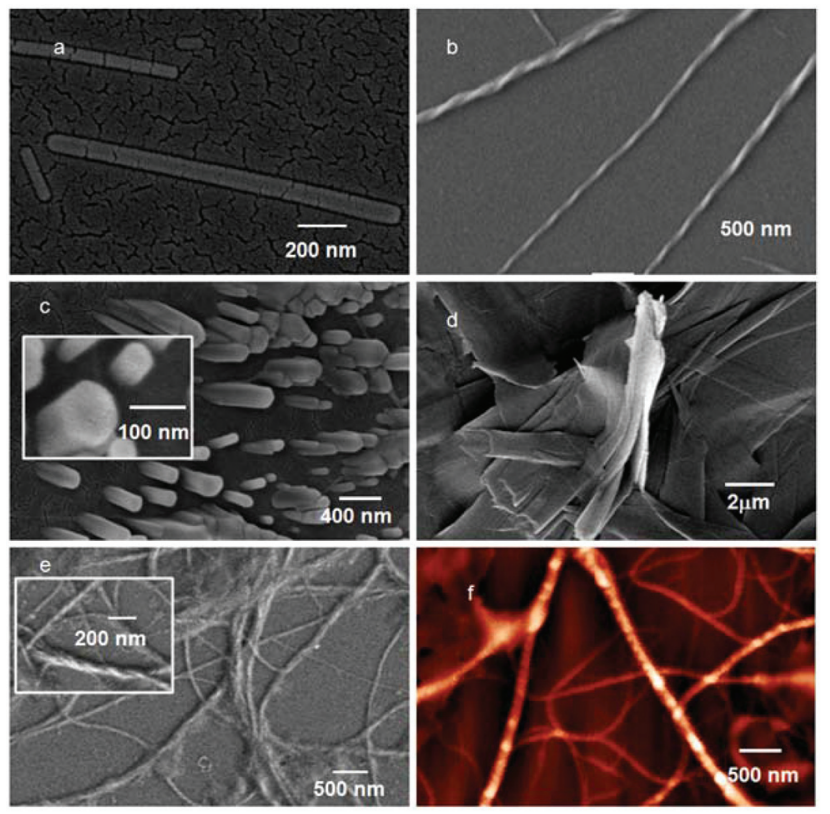

Fig. 4 FE-SEM images of (a) peptide 1 showing an unbranched polydisperse nanotubes morphology; (b) coumarin derivative 2 having a twisted fiber and rope like morphology; (c) unbranched polydisperse rod-like morphology of the peptide 1 and coumarin derivative 2 mixture. (Inset: Hexagonal rod-like structures); (d) naphthalene diimide 3 showing a sheet like morphology; (e) peptide 1 and naphthalene diimide 3 mixture exhibits a very long fiber of the supramolecular polymer. (Inset: The fibers entangled like a rope) (f) AFM topology of the peptide 1 and naphthalene diimide 3 showing a very rough fiber surface. 
components in hexagonal rods was confirmed by NMR spectroscopy (Fig. S9 in the ESI $\dagger$ ). We have also studied the modular encapsulation of tripeptide $\mathbf{1}$ with naphthalene diimide 3 having hydrophobic dodecyl chains in both termini. The absorption as well as emission spectra exhibit the interaction between the peptide $\mathbf{1}$ and naphthalene diimide $\mathbf{3}$. We have also studied the morphology of naphthalene diimide 3 in DCM solution. Naphthalene diimide 3 exhibits a polydisperse layered sheet like morphology (Fig. 4d). However, the peptide 1 and naphthalene diimide 3 mixture exhibits a long fiber like morphology (Fig. 4e). The average diameter of the fibers is ca. $100 \mathrm{~nm}$ and they are several micrometers in length. The fibers also entangle like a rope. The homogeneity of the twist sense is due to chiral induction and the presence of two chiral L-amino acids in peptide 1. To investigate the topology of the fibers, atomic force microscopy (AFM) studies were performed. AFM shows a fiber like morphology (Fig. 4f). The 3D image of peptide $\mathbf{1}$ and naphthalene diimide $\mathbf{3}$ fibers indicates that the fiber surface is very rough. These microscopy studies confirm the fabrication of a long supramolecular polymer from peptide $\mathbf{1}$ and diimide $\mathbf{3}$. The docking studies also show the formation of a supramolecular polymer (ESI, Fig. S32 and S33†). So, the encapsulation is modular and one can develop different morphologies using long chain alkanes or branched alkanes instead of 2 and 3.

\section{Mass spectrometric analysis}

Furthermore, we have performed the analysis of the hexagonal column obtained from peptide $\mathbf{1}$ and compound 2 and an unbranched fiber from peptide $\mathbf{1}$ and diimide $\mathbf{3}$ by mass spectrometry. Experimental and simulated isotopic patterns of the hexagonal column obtained from peptide $\mathbf{1}$ and compound 2 are depicted in Fig. $5 .{ }^{18}$ The mass spectrum peak at $\mathrm{m} / \mathrm{z}$ 855.4801, which was assigned to the ion [(peptide $1+$ compound 2) $+\mathrm{Na}]^{+}$shows the existence of the peptide $\mathbf{1}$ and compound 2 conjugate. The mass spectrum analysis of the unbranched fiber from peptide $\mathbf{1}$ and diimide $\mathbf{3}$ exhibits a peak at $m / z$ 1514.2728, which was assigned to the ion $[(2 \text { peptide } 1+\text { diimide } 3)+2 \mathrm{~K}]^{+}$that shows the existence of the peptide 1 and compound 3 conjugate (Fig. S10 in the ESI†).
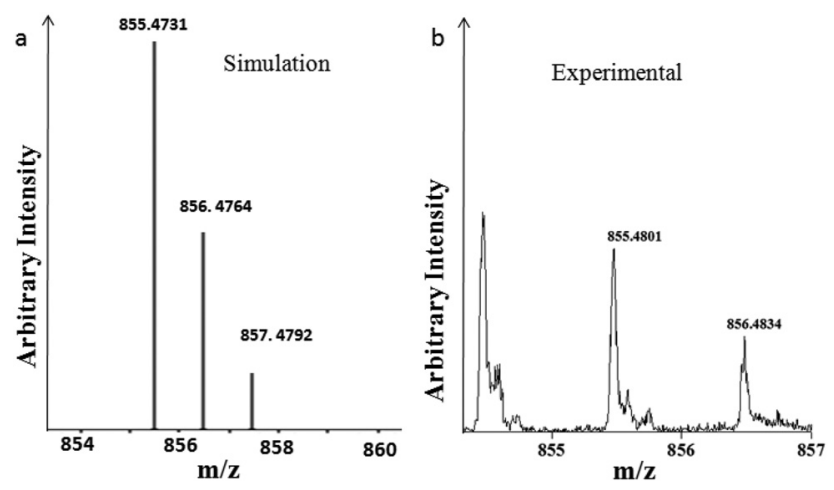

Fig. 5 Mass spectrum of the hexagonal column obtained from peptide 1 and compound 2. (a) Simulated and (b) experimental isotopic patterns.

\section{Conclusions}

We have presented a supramolecular helix from a tripeptide, which can interact with various hydrophobic guests. In organic solvents, the tripeptide 1 forms rigid type-III' $\beta$-turn structure.

In hierarchical association, the modular building blocks self-assemble in a helical manner to form supramolecular nanotubes with a hydrophobic core. The coumarin derivative 2 having a hydrophobic tail interacts with the nanotube by incorporating the hydrophobic tail inside the nanotube. However, the naphthalene diimide $\mathbf{3}$ having two hydrophobic tails interacts with the nanotube by incorporating its hydrophobic tails inside two nanotubes and thus develops a supramolecular polymer. Further the formation of supramolecular polymer has been confirmed with DLS, SEM and AFM and other spectroscopic techniques. The developed strategy could find important application in drug formulation and delivery, sensor technology and materials science.

\section{Acknowledgements}

This work is supported by CSIR, New Delhi, India (Project No. 02(0206)/14/EMR-II). This work is also supported by UGC, India (fellowship to A. Paikar) and CSIR, India (fellowship to A. Pramanik and T. Das).

\section{Notes and references}

1 (a) L. Yang, X. Tan, Z. Wang and X. Zhang, Chem. Rev., 2015, 115, 7196; (b) L. Brunsveld, B. J. B. Folmer, E. W. Meijer and R. P. Sijbesma, Chem. Rev., 2001, 101, 4071; (c) T. F. A. De Greef, M. M. J. Smulders, M. Wolffs, A. P. H. J. Schenning, R. P. Sijbesma and E. W. Meijer, Chem. Rev., 2009, 109, 5687; (d) R. Chakrabarty, P. S. Mukherjee and P. J. Stang, Chem. Rev., 2011, 111, 6810; (e) S. J. Rowan, S. J. Cantrill, G. R. L. Cousins, J. K. M. Sanders and J. F. Stoddart, Angew. Chem., Int. Ed., 2002, 41, 898; $(f)$ C. Schmuck and H. Wennemers, in Highlights in Bioorganic Chemistry, Wiley-VCH Verlag GMBH, Weinheim, 2004.

2 (a) G. Yu, K. Jie and F. Huang, Chem. Rev., 2015, 115, 7240; (b) Z. Huang, S.-K. Kang, M. Banno, T. Yamaguchi, D. Lee, C. Seok, E. Yashima and M. Lee, Science, 2012, 337, 1521; (c) W. Zhang, W. Jin, T. Fukushima, A. Saeki, S. Seki and T. Aida, Science, 2011, 334, 340; (d) P. Cordier, F. Tournilhac, C. S. Ziakovic and L. Leibler, Nature, 2008, 451, 977; (e) T. Aida, E. W. Meijer and S. I. Stupp, Science, 2012, 335, 813; $(f)$ E. Persch, O. Dumele and F. Diederich, Angew. Chem., Int. Ed., 2015, 54, 3290; $(g)$ E. Krieg, M. M. C. Bastings, P. Besenius and B. Rybtchinski, Chem. Rev., 2016, 116, 2414.

3 (a) S. Hecht and I. Huc, in Foldamers: structure, properties and applications, Wiley-VCH Verlag GMBH, Weinheim, 
2007; (b) P. Jana, S. Maity, S. K. Maity, P. K. Ghorai and D. Haldar, Soft Matter, 2012, 8, 5621; (c) M. J. Frampton and H. L. Anderson, Angew. Chem., Int. Ed., 2007, 46, 1028; (d) C. H. Görbitz, Chem. - Eur. J., 2007, 13, 1022; (e) X. Du, J. Zhou, J. Shi and B. Xu, Chem. Rev., 2015, 115, 13165.

4 (a) A. Harada, Y. Takashima and H. Yamaguchi, Chem. Soc. Rev., 2009, 38, 875; (b) G. Crini, Chem. Rev., 2014, 114, 10940; (c) G. Chen and M. Jiang, Chem. Soc. Rev., 2011, 40, 2254.

5 (a) J. W. Lee, S. Samal, N. Selvapalam, H.-J. Kim and K. Kim, Acc. Chem. Res., 2003, 36, 621; (b) K. Kim, Chem. Soc. Rev., 2002, 31, 96.

6 (a) C. J. Brown, F. D. Toste, R. G. Bergman and K. N. Raymond, Chem. Rev., 2015, 115, 3012; (b) J. Kang and J. Rebek, Nature, 1997, 385, 50.

7 R. Villalonga, R. Cao and A. Fragoso, Chem. Rev., 2007, 107, 3088.

8 (a) S. J. Barrow, S. Kasera, M. J. Rowland, J. del Barrio and O. A. Scherman, Chem. Rev., 2015, 115, 12320; (b) J. M. Haider and Z. Pikramenou, Chem. Soc. Rev., 2005, 34, 120.

9 (a) X. Ma and Y. Zhao, Chem. Rev., 2015, 115, 7794; (b) R. Haag, Angew. Chem., Int. Ed., 2004, 43, 278; (c) C. J. Porter, N. L. Trevaskis and W. N. Charman, Nat. Rev. Drug Discovery, 2007, 6, 231; (d) C. A. Lipinski, J. Pharmacol. Toxicol. Methods, 2000, 44, 235; (e) F. Hirayama and K. Uekama, Adv. Drug Delivery Rev., 1999, 36, 125.

10 (a) D. Nishimura, T. Oshikiri, Y. Takashima, A. Hashidzume, H. Yamaguchi and A. Harada, J. Org. Chem., 2008, 73, 2496; (b) T. Oshikiri, Y. Takashima, H. Yamaguchi and A. Harada, J. Am. Chem. Soc., 2005, 127, 12186.

11 (a) C. Bao, B. Kauffmann, Q. Gan, K. Srinivas, H. Jiang and I. Huc, Angew. Chem., Int. Ed., 2008, 47, 4153; (b) H. P. Yi, C. Li, J. L. Hou, X. K. Jiang and Z. T. Li, Tetrahedron, 2005,
61, 7974; (c) B. Prince, S. A. Barnes and J. S. Moore, J. Am. Chem. Soc., 2000, 122, 2758; (d) R. A. Dwek, Chem. Rev., 1996, 96, 683; (e) H. Abe, N. Masuda, M. Waki and M. Inouye, J. Am. Chem. Soc., 2005, 127, 16189; (f) C. Y. Tan, M. R. Pinto, M. E. Kose, I. Ghiviriga and K. S. Schanze, Adv. Mater., 2004, 16, 1208.

12 Q. Gan, Y. Ferrand, C. Bao, B. Kauffmann, A. Grélard, H. Jiang and I. Huc, Science, 2011, 331, 1172.

13 (a) P. Jana, S. Maity, S. K. Maity and D. Haldar, Chem. Commun., 2011, 47, 2092; (b) A. K. Das, A. Banerjee, M. G. B. Drew, S. Ray, D. Haldar and A. Banerjee, Tetrahedron, 2005, 61, 5027; (c) S. K. Maji, A. Banerjee, M. G. B. Drew, D. Haldar and A. Banerjee, Tetrahedron Lett., 2002, 43, 6759.

14 I. L. Karle, Acta Crystallogr., Sect. B: Struct. Sci., 1992, 48, 341.

$15 \mathrm{C}_{19} \mathrm{H}_{35} \mathrm{~N}_{3} \mathrm{O}_{7}, M_{\mathrm{W}}=417.50$, hexagonal, space group $P 65, a=$ $19.7793(8), b=19.7793(8), c=11.2095(7) \AA, V=3797.8(4)$ ̊3, $Z=6, \mathrm{dm}=1.095 \mathrm{Mg} \mathrm{m}^{-3}, T=100 \mathrm{~K}, R_{1} 0.0591$ and $\mathrm{w} R_{2} 0.1625$ for 4990 data with $I>2 \sigma(I)$. Intensity data were collected with MoK $\alpha$ radiation using a Bruker APEX-2 CCD diffractometer. Data were processed using the Bruker SAINT package and the structure solution and refinement procedures were performed using SHELX $97^{19}$ and deposited at CCDC with reference 1434362.

16 V. Moretto, M. Crisma, G. M. Bonora, C. Toniolo, H. Balaram and P. Balaram, Macromolecules, 1989, 22, 2939.

17 S. K. Maji, R. Banerjee, D. Velmurugan, A. Razak, H. K. Fun and A. Banerjee, J. Org. Chem., 2002, 67, 633.

18 A. A. Nazarov, S. M. Meier, O. Zava, Y. N. Nosova, E. R. Milaeva, C. G. Hartinger and P. J. Dyson, Dalton Trans., 2015, 44, 3614.

19 G. M. Sheldrick, SHELX 97, University of Göttingen, Germany, 1997. 